\title{
Fournier's Gangrene: 10-Year Experience of a Plastic Surgery and Burns Department at a Tertiary Hospital
}

\author{
Gangrena de Fournier: 10 Anos de Experiência de um \\ Serviço de Cirurgia Plástica e Queimados num Hospital \\ Terciário
}

\author{
João Mendes LOURO $\otimes^{1}$, Miguel ALBANO'1, João BALTAZAR², Miguel VAZ², Carla DIOGO², Sara RAMOS², \\ Luís CABRAL ${ }^{2}$ \\ Acta Med Port 2019 May;32(5):368-374 - https://doi.org/10.20344/amp.11003
}

\section{ABSTRACT}

Introduction: Fournier gangrene is a polymicrobial life threatening infection of perineal subcutaneous soft tissues with its point of origin in urologic, colorectal or skin diseases. Although more frequent in elderly and men, it can affect all genders and age groups. Perianal abscess, diabetes mellitus and Escherichia coli are the most frequent cause, predisposing comorbidity, and microorganism found in tissue culture analysis respectively. The objective of this study was to describe the experience of a Plastic Surgery Department of a tertiary Hospital in reconstructing Fournier's gangrene perineal defects and its detailed demography.

Material and Methods: The sample is composed of all patients with Fournier gangrene admitted in the Plastic Surgery and Burns Department. The authors retrospectively collected and analyzed demographic and clinical data during a period of 10 years including gender, age, length of stay, cause, number of debridements, predisposing factors, microbial culture results, surgical reconstructive techniques and its associated complications, additional surgical procedures and outcomes.

Results: Fifteen patients were identified: 14 males (93\%) and one female (7\%); mean age was 66.9 years (range: 46 - 86); mean, length of stay was 46.8 days (range: 20 - 71 days) and mean number of debridements was 3.3 (range: 1 - 4). The most frequent predisposing factor was diabetes mellitus, the major cause was perianal $(n=2)$ and skin abscess $(n=2)$. Eight $(53.3 \%)$ patients had no identifiable source of Fournier gangrene. Various types of reconstructive techniques were employed; and 5 additional surgical interventions $(33.3 \%)$ were undertaken (one cystostomy, two orchidectomy, two ileostomy); six patients $(40 \%)$ presented reconstructive technique complications with adequate final outcome.

Discussion: In contrast with the literature, where Escherichia coli was the most frequently isolated agent, Staphylococcus aureus was the most frequent microorganism found in tissue biopsy/pus collection analysis. A higher than expected number of patients $(n=8)$ had no identifiable source of Fournier gangrene. This findings can be explained by the retrospective non-multicentre study limitation, with a potencial source of bias patients that were transferred from other hospitals in advanced stage, without point of origin of Fournier's gangrene identified.

Conclusion: Early recognition and extensive necrotic tissue debridement, along with prompt and adequate antimicrobial treatment, are the mainstay of Fournier gangrene management, thus reducing morbidity and mortality in these patients. Surgical reconstruction challenges derived from this condition should be addressed by specialized teams due to the risk of dysfunctional sequelae and conspicuous deformities. Taking in account the single-center and retrospective observational character of the present study, these premises require proper validation from a multicenter prospective study.

Keywords: Fournier Gangrene/surgery; Fasciitis, Necrotizing Plastic Surgery; Portugal; Reconstructive Surgical Procedures

RESUMO

Introdução: A gangrena de Fournier é uma infeção polimicrobiana potencialmente fatal que afeta os tecidos moles do períneo com ponto de origem em patologias urológicas, coloretais ou cutâneas. Apesar de ser mais frequente no sexo masculino e em idosos, pode afetar ambos os géneros e qualquer idade. O abcesso perianal, a diabetes mellitus e a Escherichia coli são respetivamente a causa, a co-morbilidade e o micro-organismo mais frequentemente encontrados. Este estudo teve como objetivo descrever a experiência de um Serviço de Cirurgia Plástica e Queimados de um Hospital terciário no tratamento e reconstrução de defeitos perineais causados por gangrena de Fournier, disponibilizando detalhes sobre a sua demografia.

Material e Métodos: A amostra é constituída por todos os doentes internados no serviço de Cirurgia Plástica e Queimados com o diagnóstico de gangrena de Fournier. Os autores realizaram uma colheita e análise retrospetiva de dados clínicos e demográficos durante um período de 10 anos incluindo género, idade, tempo de internamento, causa, número de desbridamentos, fatores predisponentes, resultados microbiológicos de culturas de pus, técnicas reconstrutivas cirúrgicas e suas complicações, intervenções cirúrgicas adicionais e o resultado final.

Resultados: Foram identificados 15 doentes: 14 homens (93\%) e uma mulher (7\%); a idade média foi 66,9 anos (amplitude: 46 - 86); tempo médio de internamento foi 46,8 dias (amplitude: 20 - 71 dias) e o número médio de desbridamentos foi 3,3 (amplitude: 1 - 4). 0 fator predisponente mais frequente foi a diabetes mellitus, e as causas mais frequentes o abcesso perianal $(n=2)$ e o abcesso cutâneo $(n=2)$. Em oito $(53,3 \%)$ doentes não foi identificada a causa da gangrena de Fournier. Foram utilizadas várias técnicas reconstrutivas e realizadas conco $(33,3 \%)$ intervenções cirúrgicas adicionais (uma cistostomia, duas orquidectomias, duas ileostomias); seis doentes $(40 \%)$ apresentaram complicações de técnicas reconstrutivas com resultado final adequado.

Discussão: O micro-organismo mais frequentemente isolado nas culturas de pus foi o Staphylococcus aureus, o que contrasta com a literatura onde a Escherichia coli é o agente mais frequentemente isolado. Foi identificado um número superior ao esperado de

1. Department of General Surgery. Coimbra Hospital and University Centre. Coimbra. Portugal.

2. Department of Plastic Surgery and Burns. Coimbra Hospital and University Centre. Coimbra. Portugal.

$\bowtie$ Autor correspondente: João Mendes Louro. joaomendeslouro@gmail.com

Recebido: 01 de julho de 2018 - Aceite: 10 de dezembro de 2018 | Copyright @ Ordem dos Médicos 2019 
doentes sem causa identificável $(n=8)$ de gangrena de Fournier. Estes achados podem ser explicados pelo facto de se tratar de um estudo retrospetivo multicêntrico, com um potencial viés por existirem doentes que foram transferidos de outras institucões em estado avançado de doença, sem foco de origem de gangrena de Fournier identificado.

Conclusão: O precoce reconhecimento e extenso desbridamento do tecido necrosado, em conjunto com um adequado tratamento antibiótico, são os pilares do tratamento da gangrena de Fournier reduzindo assim a morbilidade e mortalidade destes doentes. Os desafios cirúrgicos reconstrutivos que advêm desta patologia devem ser abordados por uma equipa especializada, pelo risco de sequelas funcionais e estéticas. Tendo em conta o carater observacional, retrospetivo e unicêntrico do presente estudo, estas premissas requerem uma validação adequada através de um estudo prospetivo e multicêntrico.

Palavras-chave: Cirurgia Plástica; Fasciite Necrosante; Gangrena de Fournier/cirurgia; Portugal; Procedimentos Cirúrgicos Reconstrutivos

\section{INTRODUCTION}

Fournier's gangrene (FG) is a severe infection affecting subcutaneous soft tissues of the perineum, perianal and genital zones. It results from a breach in the integrity of the urethral or gastrointestinal mucosa, creating a rapidly progressive and life threatening type of necrotizing fasciitis. ${ }^{1,2}$ Muscle cells are less frequently affected due to its rich vascularisation. ${ }^{3}$ This condition is more frequently diagnosed in males (10:1) and in the elderly, ${ }^{4,5}$ but may affect patients of all genders and ages. Despite a low prevalence (3 - 7/ $1000000)^{6}$, mortality rate can reach up to $40 \%$. $^{7}$

FG is usually a symbiotic polymicrobial infection caused by aerobic and anaerobic bacterial flora, arising from the low gastrointestinal (i.e. perianal/ischiorectal abscess) or genitourinary tracts, (i.e. urinary tract infection, traumatic catheterization) or from the skin (i.e. perineal skin abscess, allergic reactions). ${ }^{8}$ Immunosuppressed patients due to concomitant conditions like diabetes mellitus (DM), chronic ethanol abuse, malignancies, liver cirrhosis, HIV infection, organ transplantation or steroids use have a higher risk of developing the disease..$^{4,7}$

Early recognition of clinical signs is imperative: the spread rate of the necrotizing fasciitis can be as high as $2-3 \mathrm{~cm} /$ hour, rapidly progressing to the gluteal muscles, scrotum, penis, abdominal and thoracic wall. ${ }^{9-11}$ The clinical presentation is variable, but suspicion should be high when abrupt severe pain is present and associated with ecchymosis, fever, and cutaneous anaesthesia; rarely, subcutaneous gas with crepitation may be present. ${ }^{12-14}$ Conventional X-rays may show subcutaneous gas, however, the best imaging modality is a computed tomography (CT) scan that allows a more precise assessment of the extension and depth of the infection as well as the presence of abscesses. ${ }^{15,16}$

Early antibiotic administration and urgent surgical drainage along with debridement of necrotic tissues are critical for sepsis control in FG. Debridements may create major defects presenting great reconstructive challenges. ${ }^{17}$

The purpose of this study is to analyse demographic, clinical and surgical data of all patients with FG admitted at the Plastic Surgery and Burns Department of a tertiary hospital, in Coimbra, Portugal, during a ten-year period and compare it to the available literature.

\section{MATERIALS AND METHODS} ed.

\section{Study population}

Observational retrospective analysis of patients with Fournier's gangrene admitted to the Plastic Surgery and Burns Department of Centro Hospitalar e Universitário de Coimbra (Hospital and University Centre of Coimbra - CHUC), Coimbra, Portugal, during a period of 10 years (from January $1^{\text {st }}, 2007$, to December 31 st, 2016).

Demographic and clinical data were collected from medical records including age, gender, predisposing factors/aetiology, comorbidities, number and nature of surgical interventions, culture findings, length of stay (LOS) and clinical outcome.

Retrospectively reviewing the medical records allowed us to only include in our cohort, patients with confirmed FG on histology; this process minimised selection bias.

\section{Limitations of the study}

Retrospective non-multicenter study.

\section{Statistical analysis}

All data were collected and analysed using Microsoft ${ }^{\circledR}$ Excel $^{\circledR}$ for Mac 2011, version 14.7.1 (161129).

\section{RESULTS}

Fifteen patients with $\mathrm{FG}$ were identified: fourteen males $(93 \%)$ and one female $(7 \%)$. The mean age was 66.9 years (range: 46 - 86). The mean LOS was 46.8 days (range: 20 - 71 days). The mean number of debridements was 3.3 (range: 1 - 4). There were no fatalities in this group of patients (Table 1).

The most common identified causes were perianal $(\mathrm{n}=$ 2: $13.3 \%)$ and skin abscesses $(n=2: 13.3 \%)$; other causes included bartholinitis $(n=1: 6.7 \%)$, perineal trauma $(n=1$ : $6.7 \%)$ and hernioplasty suture site infection ( $n=1: 6.7 \%)$. In 8 patients $(53.3 \%)$ there was no identifiable point of origin of FG. DM was the most frequent comorbidity $(n=6$ : $40 \%$ ); other predisposing factors were identified namely

\section{Table 1 - Demographic and clinical data}

\begin{tabular}{lc}
\hline & $\mathbf{n}(\% /$ range $)$ \\
\hline Gender & \\
Male & $14(93 \%)$ \\
Female & $1(7 \%)$ \\
Age (range) & $66.9(46-86)$ \\
LOS (range) & $46.8(20-71)$ \\
Number of debridements (range) & $3.3(1-4)$ \\
\hline
\end{tabular}


Table 2 - Causes and predisposing factors

Causes
Idiopathic
Perianal abscess
Skin abscess
Bartholinitis
Perineal trauma
Hernioplasty suture site infection
Predisposing factors
Diabetes mellitus
No isolated predisposing factor identified
Monoclonal gammopathy of undetermined significance
Chronic renal failure
Alcoholic cirrhosis
Colon cancer

monoclonal gammopathy of undetermined significance, chronic renal failure, alcoholic cirrhosis and colon cancer, with one case each (Table 2).

Cultures of pus were obtained in all 15 surgical wounds (Table 3 ): seven patients $(46.7 \%)$ had mixed microorganisms (MO) (mixture of aerobic \pm anaerobic \pm fungus); 6 patients $(40 \%)$ had one bacterial isolation, and two patients $(13.3 \%)$ had negative microbiological results. The most frequent $\mathrm{MO}$ found was Staphylococcus aureus $(\mathrm{n}=7$ : $46.7 \%$ ), followed by Enterococcus faecalis ( $n=5: 33.3 \%$ ), Escherichia coli $(\mathrm{n}=3,20 \%)$, Acinetobacter baumannii ( $\mathrm{n}$ $=3,20 \%$ ) and Pseudomonas aeruginosa ( $n=2,13.3 \%$ ); other bacteria were only present in one culture each: Streptococcus pyogenes, Enterococcus faecium, Enterococcus cloacae, Klebsiella pneumoniae, Streptococcus epidermidis, Bacteroides fragilis, Corynebacterium, Candida albicans and Aspergillus fumigatus. Fig. 1 shows all MO found in culture results. Monomicrobial bacteria culture identification was present in 6 patients: Escherichia coli $(\mathrm{n}=2,13.3 \%)$, Staphylococcus aureus ( $\mathrm{n}=2,13.3 \%)$, and Corynebacterium and Enterobacter cloacae isolated in one patient each. One patient had multidrug resistant Staphylococcus aureus. Anaerobic bacteria (Bacteroides fragilis) were identified in one patient $(6.7 \%)$.

All patients were subjected to reconstructive surgical

Table 3 - Culture results

\begin{tabular}{lc}
\hline & $\mathbf{n}(\%)$ \\
\hline Mixed MO culture result & $\mathbf{7}(\mathbf{4 6 . 7 )}$ \\
Monomicrobial culture result & $\mathbf{6}(\mathbf{4 0 . 0 )}$ \\
Escherichia coli & $2(13.3)$ \\
Staphylococcus aureus & $2(13.3)$ \\
Corynebacterium & $1(6.7)$ \\
Enterobacter & $1(6.7)$ \\
Negative culture result & $\mathbf{2 ( 1 3 . 3 )}$ \\
Total & $\mathbf{1 5 ( 1 0 0 . 0 )}$ \\
\hline
\end{tabular}

procedures (Table 4$)$. In 5 patients (33.3\%) the only reconstructive surgery performed was a split thickness skin graft (STSG). Eight patients (53.3\%) had one reconstructive surgery with flaps (one scrotal reconstruction with bilateral internal pudendal pedicled flaps; one scrotal reconstruction with contralateral rotational flap; one internal thigh bilateral fasciocutaneous transposition flaps; one vulvar reconstruction with McGregor propeller flap; one pedicled anterolateral thigh (ALT) flap with tunnelling to the defect; one local sliding flap; one medial femoral circumflex artery perforator fasciocutaneous flap; one internal thigh rotational flap). One patient $(6.7 \%)$ needed two flap reconstructive surgeries (scrotal reconstruction with bilobed internal thigh flaps and fasciocutaneous transposition flaps for perineal defects closure, and one patient $(6.7 \%)$ had a full thickness skin graft for reconstruction of a degloved penis shaft. Derivative ileostomy was performed in two patients $(13.3 \%)$, and diverting cystostomy in one $(6.7 \%)$. In addition to scrotal, vulvar and perineal reconstruction, two patients (13.3\%) required unilateral orchidectomy (Table 4).

Regarding complications, three patients (20\%) presented partial skin graft loss, two patients (13.3\%) suffered skin flap partial suture dehiscence and there was one case $(6.7 \%)$ of partial necrosis of the skin flap (Table 5).

\section{DISCUSSION}

FG is characterized by a rapidly progressive potentially fatal necrotizing infection of the external genitalia and perineum that can spread along Buck's fascia of the penis, Colle's fascia of the perineum and extend to Scarpa's fascia of the anterior abdominal wall, sometimes even reaching the thoracic wall. This necrosis is caused by vessel obliteration related to polymicrobial proliferation along the fascial plane, generating oedema, microthrombosis and hypoxia, favouring anaerobic bacteria overgrowth. ${ }^{18}$ In the present study, only one patient was confirmed to be infected with anaerobic bacteria (Bacteroides fragilis). Regardless, one should consider that false negatives for anaerobic bacteria 


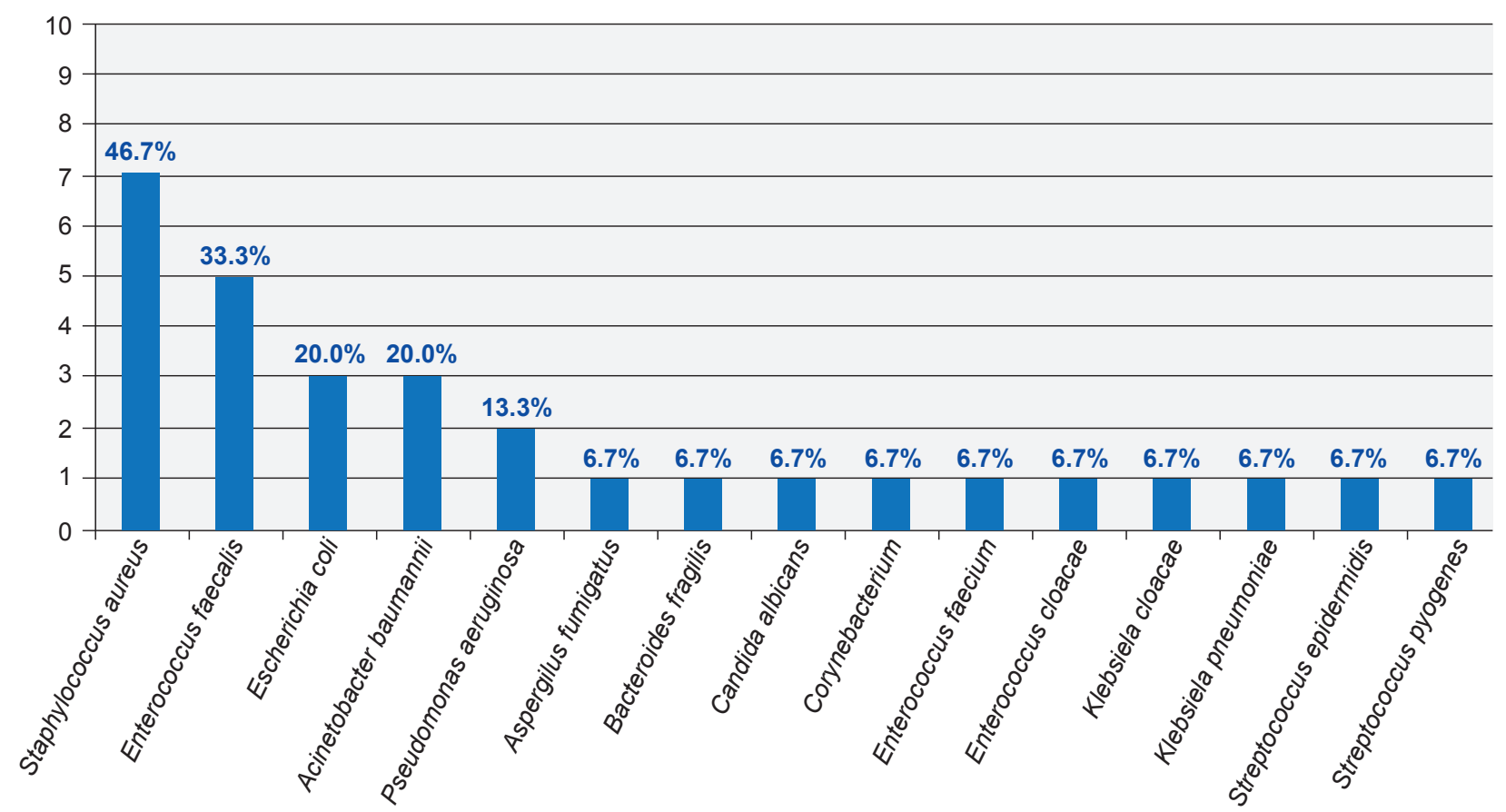

Figure 1 - Microorganisms found in al culture results of patients with Fournier's gangrene

in biopsy cultures are a frequent finding and do not exclude their presence. One can postulate that more anaerobic pathogens would have been identified if routinely searched for in appropriate tissue biopsies.

In this study, the most common cause of FG was perineal abscess: 4 patients $(26.7 \%)-2$ perianal and 2 skin abscesses. Three patients $(20 \%)$ had other causes (bartholinitis, perineal trauma, hernioplasty suture site infection) and more than half of the patients $(n=8: 53.3 \%)$ had no identifiable cause of FG. There was an unexpected inversion in statistics because idiopathic FG usually accounts for $25 \%$ of the group and perineal abscess (perianal and skin abscess) around 50\%.15,19,20 However, when the diagnosis is delayed to later stages of the disease it becomes more difficult to identify the primary source. Some of the idiopathic cases of FG might have originated from colorectal or skin sources even though the authors could not find such information in the clinical records.

This retrospective 10-year analysis found a rather low number of patients with FG - only 15 patients. A possible explanation might be the fact that the study sample is composed only by patients admitted to Plastic Surgery and

Table 4 - Surgical procedures performed

\section{Reconstructive surgical procedures}

Split skin graft (as the only procedure performed)

Internal pudendal pedicled flap

Contralateral rotational flap

Internal thigh bilateral fasciocutaneous transposition flaps

McGregor propeller flap

Local sliding flaps

Medial femoral circumflex artery perforator fasciocutaneous flap

Internal thigh rotational flap

Bilobed internal thigh flaps

Full thickness graft

\section{Additional surgical procedures}

Derivative ileostomy

Diverting cystostomy

Orchidectomy 
Table 5 - Complications after reconstructive surgery

\begin{tabular}{lc}
\hline & $\mathbf{n}(\%)$ \\
\hline Partial skin graft loss & $3(20.0)$ \\
Skin flap partial dehiscence & $2(13.3)$ \\
Skin flap partial necrosis & $1(6.7)$ \\
Total & $6(40.0)$ \\
\hline
\end{tabular}

Burns Department. All patients were initially operated in the General Surgery or Urology Departments, and most of them were also treated there, which may underestimate the actual number. In addition, some of these patients also had the first debridement in another institution. They were transferred to CHUC only after stabilization and septic source control in order to have further debridement and reconstructive surgery, and might have been registered as cutaneous ulcers of undetermined origin.

Commonly, wound cultures are polymicrobial with mixed aerobic and anaerobic bacteria. Our findings corroborate this data, as shown in Table 1. On the other hand, the most frequent bacteria usually found in the literature is Escherichia coli with a frequency of $43 \%-80 \%{ }^{20}$ which contrasts with our group where the most frequent one was Staphylococcus aureus ( $\mathrm{n}=7: 46.7 \%)$, followed by Enterococcus faecalis ( $n=5: 33.3 \%)$, Escherichia coli $(n=3,20 \%)$, Acinetobacter baumannii ( $\mathrm{n}=3,20 \%)$, Pseudomonas aeruginosa $(n=2,13.3 \%)$ and other bacteria only present in one culture each (Bacteroides fragilis, Corynebacterium, Enterococcus cloacae, Enterococcus faecium, Klebsiella pneumoniae, Streptococcus pyogenes, Streptococcus epidermidis). There were also two fungal specimens isolated, namely Aspergillus fumigatus and Candida albicans. It is the authors' consideration that microbial cultures were not systematically obtained (pus collection versus tissue biopsy) or registered in clinical records of all patients. Furthermore, one can suggest another simple explanation for the high number of negative cultures obtained, and possible false negatives: the fact that many samples obtained were indeed sterile necrosis due to the widespread use of local (i.e. silver sulfadiazine) or systemic antibiotic therapy and the use of antiseptic solutions (i.e. chlorohexidine, iodopovidone); other reasons may be contamination at the Burn Unit and/or the timing of sampling for culture analysis.

In this study, DM had an incidence of $40 \%$, which is similar to other series like Korkut et al with an incidence of $46 \%$ - $76.9 \%{ }^{21}$. Other predisposing factors with lower incidence were also found (alcoholic cirrhosis, chronic renal failure, colon cancer and monoclonal gammopathy of undetermined significance) and all of them might have contributed to the severity of the disease. Five patients had no isolated predisposing factor identified.

No fatalities were verified, which contrasts with the literature with mortality rates reaching up to $40 \% .^{7}$ This can be due to early necrotic debridement, early antibiotic prescribing, and to the fact that the majority of our patients got ward beds at the Burn Unit, where complete aseptic care is provided, besides closer monitoring and antimicrobial stewardship. This absence of casualties might also reflect a selection bias as patients with the worst outcomes were frequently first admitted in the Intensive Care Units and eventually die before they were fit to undergo reconstructive surgery.

Some authors propose the use of prognostic factor outcome predictors: Laor et $a^{22}$ created the Fournier Gangrene Severity Index (FGSI) that gathers clinical (fever, respiratory rate, heart rate) and laboratory data (serum sodium, potassium, bicarbonate, creatinine, haematocrit and white blood cell count) allowing to predict patients' prognosis and mortality: when the score $>9$, the mortality can reach up to $75 \%$, and if $<9$ survival can be expected in $78 \%$ of the patients, but many authors like Tuncel et $a^{23}$ argue that the index cannot be relied on to predict mortality alone; Friederichs et $a^{24}$ state that procalcitonin (PCT) ratio levels 1 or 2 days after surgical debridement may be a valuable indicator of infection source elimination, indicating that when PCT values rises, wider margin debridement is required. Kincius $\mathrm{M}$ et $\mathrm{a}^{25}$ evaluated the feasibility of predicting the outcome using the LRINEC (Laboratory Risk Indicator for Necrotizing Fasciitis) score using laboratory data (C-reactive protein, sodium, white blood cell count, hemoglobin, serum sodium, creatinine and glucose); they concluded that a score higher than 9 can be used as a high-value threshold predictor of death during the first evaluation of patients with $F G$.

According to Taken et al, ${ }^{18}$ the management of FG can be divided in four main steps: rapid and aggressive debridement of necrotic tissue, resuscitation and hemodynamic/ fluid support, empirical broad spectrum parenteral antibiotic therapy and sterile wound dressing. It is the opinion of the authors that reconstructive surgery should definitely be added as a fifth parameter, improving outcomes and quality of life.

In this series we found a mean of 3.33 necrotic tissue debridements per patient with a range between 1 and 4 . When tissue vitality was doubtful, after the first wide necrosectomies, additional tissue debridements were undertaken, guided by the extension of the necrosis beyond the wound limits due to progression of the infectious process. A higher number of debridements may be related with worse prognosis and a higher mortality rate ${ }^{26}$ given the fact that the infection source is not completely eradicated after the first surgical procedure. Conversely, patients with less severe disease would require less surgical debridements. Despite this popular belief, Laor et $a^{22}$ state that the number of debridements is not related with worse prognosis. The fact that patients with less severe disease, in contrast with nonsurvivors, will have more time to be undergo multiple debridements, will allow infection eradication and tissue healing with better outcomes. Other treatment' adjuvants were sometimes employed but in a non-systematic way, like the use of vacuum therapy. When available, hyperbaric oxygen therapy (HOT) is treatment of great value, since it can optimize infected tissue oxygenation, and has bacteriostatic and bactericide properties. ${ }^{27}$ However, none of the patients had access to HOT. 
Additional surgical interventions were undertaken in five patients $(33.3 \%)$ : two ileostomies $(13.3 \%)$, one cystostomy $(6.7 \%)$ and two orchidectomies (13.3\%). Surgical faecal diversion aims to reduce perineal wound contamination when there is anal sphincter involvement, faecal incontinence or continued wound contamination. Nevertheless, it increases morbimortality and health care costs. Paying attention to these facts, rectal sealing collecting systems, like FlexiSeal Faecal Management System ${ }^{\circledR}$, may be considered as the first faecal diversion of choice. ${ }^{28,} 29$ When a surgical faecal diversion is deemed necessary, the procedure elected is usually a colostomy. In the present series however, two ileostomies were performed because one patient had been subjected to left hemicolectomy and the other had a left colon cancer. Both patients had their ileostomy closed at a later date without complications. The incidence of surgical faecal diversion was $13.3 \%$, which is similar to the literature, which refers an incidence of $15 \%$ of colostomies performed. ${ }^{30}$ Urinary diversion is indicated when there is a large perineal wound after debridement or abscess with either urethral or extensive penile involvement. Some authors recommend urethral catheterization to achieve diversion, ${ }^{31}$ but others suggest the use of cystostomy when there is a large perineal involvement, with some series indicating that nearly half of the patients with FG receive a cystostomy for urinary diversion. ${ }^{32}$

The reconstructive option was directed to the specific patient's defect. Literature information regarding the type of reconstructive technique is vast, addressing both cosmetic and functional results as well as complications, but sometimes is somewhat difficult to interpret. Karian $L$ et $a^{\beta 3}$ concluded that given the fact that most patients with FG have serious comorbidities, the reconstructive surgical procedure should be the fastest and the least expensive because patients are at high risk of developing complications requiring longer or multiple procedures; regarding testicular exposure, if it is less than $50 \%$ of the scrotal area, Karian L et al advocate scrotal advancement flaps or healing by secondary intention; for larger defects with perianal involvement, more complex procedures should be undertaken, including skin grafts or flap reconstruction, sometimes resorting to the use of microsurgical techniques.

Regarding operative complications, Chen et al ${ }^{34}$ report an $11 \%$ rate of split-thickness skin graft partial loss, which is half of our figures (20\%). However, Carvalho et $a^{\beta 5}$ report $18 \%$ of graft infection. Karian et $a^{\beta 3}$ support the use of split thickness skin graft despite its possible complications (contraction, graft loss), which are acceptable given the simplicity and low donor-site morbidity. In this sample there was a skin flap partial dehiscence and a skin flap partial necrosis: the first was re-sutured and the second healed by secondary intention and sterile dressings, having a suitable final result. It is known that flap reconstructive surgery is more complex and more prone to donor and receiver site complications such as seroma, hematoma, wound dehiscence, donor site scaring and partial or total flap loss. In addition to these complications the surgeon must be aware of cosmetic and functional problems that must be individually addressed.

\section{CONCLUSION}

FG is a rapidly progressive necrotizing fasciitis of the perineum arising from urologic, colorectal or skin foci, and must be considered as a surgical emergency. It is more common in males and in the elderly, and DM is the most frequently associated comorbidity. Contaminating flora is often polymicrobial, and the most common causative microorganism is Escherichia coli. The present study corroborates the indications for an early, aggressive, and wide debridement, plus adequate antimicrobial therapy as the mainstay of treatment.

In the authors' opinion, surgical reconstruction challenges derived from this condition should be addressed by specialised teams due to the risk of dysfunctional sequelae and conspicuous deformities. Since the present study has a single-centre and retrospective observational character, these premises require proper validation from a multicentre prospective study.

\section{SOURCE OF BIAS}

Patients transferred from other hospitals in advanced stage, without point of origin of Fournier's gangrene identified.

\section{PROTECTION OF HUMANS AND ANIMALS}

No ethical approval was required for retrospective studies according to The National Legislation on Clinical Trials. The authors declare that the procedures followed the Helsinki Declaration of the World Medical Association.

\section{DATA CONFIDENTIALITY}

The authors declare having followed the protocols in use at their working center regarding patients' data publication.

\section{CONFLICTS OF INTEREST}

None.

\section{FUNDING SOURCES}

None.

\section{REFERENCES}

1. Laucks SS. Fournier's gangrene. Surg Clin North Am. 1994;74:1339.

2. Stephens BJ, Lathrop JC, Rice WT, Gruenberg JC. "Fournier gangrene: historic (1764-1978) versus contemporary (1979-1988) differences in aetiology and clinical importance". AM Surg. 1993;59:149-54.

3. Gozal D, Ziser A, Avigdor S, Gruenberg JC. Necrotizing fasciitis. Arch
Surg. 1986;121:233.

4. Koukouras D, Kallidonis P, Panagopoulos C, Al-Aown A, Athanasopoulos A, Rigopoulos C. Fournier's gangrene, a urological and surgical emergency: presentation of a multi-institutional experience with 45 cases. Urol Int. 2011;86:167-72. 
5. Rodríguez Alonso A, Pérez García MD, Núñez López A, Ojea Calvo A, Alonso Rodrigo A, Rodríguez Iglesias B. Fournier's Gangrene: anatomoclinical features in adults and children. Therapy update. Actas Urol Esp. 2000,24:294-306.

6. Kasper DL, Braunwald E, Fauci AS, Hauser SL, Longo DL, Jameson $\mathrm{JL}$. Harrison's principle and practice of medicine. $16^{\text {th }}$ ed. New York: McGraw-Hill; 2005.

7. Sorensen MD, Krieger JN, Rivara FP, Broghammer JA, Klein MB, Mack $C D$, et al: Fournier's gangrene: population based epidemiology and outcomes. J Urol. 2009;181;2120-6.

8. Ullah S, Khan M, Asad U, Jan M. Fournier's gangrene: a dreadfu disease. Surgeon. 2009;7,138-42.

9. Paty R, Smith A. Gangrene and Fournier's gangrene. Urol Clin North Am. 1992;19:149-62.

10. Uppot R, Levy H, Patel P. Case 54: Fournier gangrene. Radiology. 2003;226:115-7.

11. Saijo S, Kuramoto $\mathrm{Y}$, Yoshinari M, Tagami H. Extremely extended Fournier's gangrene. Dermatologica. 1990;3:228-32.

12. Mandell GL, Douglas RG, Bennett, JE, Dolin R, Blaser MJ: Cellulitis and subcutaneous tissue infections. In: Principles and practice of infectious diseases. $6^{\text {th }}$ ed. Philadelphia: Churchill Livingstone; 2005.

13. Sudarsky LA, Laschinger JC, Coppa GF, Spencer FC. Improved results from a standardized approach in treating patients with necrotizing fasciitis. Ann Surg. 1987;206:661-5.

14. Stevens DL, Bisno AL, Chambers HF, Dellinger EP, Goldstein EJ, Gorbach SL, et al. Practice guidelines for the diagnosis and management of skin and soft tissue infections: 2014 update by the infectious diseases society of America. Clin Infect Dis. 2014;59:e10-52.

15. Smith GL, Bunker CB, Dineen MD. Fournier's gangrene. Br J Urol. 1998;81:347-55.

16. Wysoki, M, Santora T, Shah R, Friedman A. Necrotizing fasciitis: CT characteristics. Radiology. 1997;203:859-63.

17. Sarvestani AS, Zamiri M, Sabouri M. Prognostic factors for Fournier's Gangrene: a 10-year experience in Southeastern Iran. Bull Emerg Trauma. 2013;1:116-22.

18. Taken K, Oncu MR, Ergun M, Eryilmaz R, Demir CY, Demir M, et al. Fournier's gangrene: Causes, presentation and survival of sixty-five patients. Pak J Med Sci. 2016,32:746-50.

19. Vick R, Carson C. Fournier's disease. Urol Clin North Am. 1999,26:8419.

20. Eke N. Fournier's gangrene: a review of 1726 cases. $\mathrm{Br} \mathrm{J}$ Surg. 2000;87:718-28.
21. Korkut M, Icoz G, Dayangac M, Akgun E, Yeniay L, Erdoğan O, et al Outcome analysis in patients with Fournier's gangrene: Report of 45 cases. Dis Colon Rectum. 2003;46:649-52.

22. Laor E, Palmer L, Tolia B, Reid RE, Winter HI. Outcome prediction in patients with Fournier's gangrene. J Urol. 1995;154:89-92.

23. Tuncel A, Aydin O, Tekdogan U, Nalcacioglu V, Capar Y, Atan A. Fournier's gangrene: three years of experience with 20 patients and validity of the Fournier's gangrene severity index score. Eur Urol. 2006;50:838-43.

24. Friederichs J, Hutter M, Hierholzer C, Novotny A, Friess H, Bühren V, et al. Procalcitonin ratio as a predictor of successful surgical treatment of severe necrotizing soft tissue infections. Am J Surg. 2013;206:368-73.

25. Kincius M, Telksnys T, Trumbeckas D, Jievaltas M, Milonas D. Evaluation of LRINEC Scale Feasibility for Predicting Outcomes of Fournier Gangrene. Surg Infect._2016;17:448-53.

26. Chawla SN, Gallop C, Mydlo JH. Fournier's gangrene: an analysis of repeated surgical debridements. Eur Urol. 2003;43:572-5.

27. Rosa I, Guerreiro F. Hyperbaric oxygen therapy for the treatment of Fournier's gangrene: a review of 34 cases. Acta Med Port. 2015;28:61923.

28. Chennamsetty A, Khourdaji I, Burks F, Killinger KA. Contemporary diagnosis and management of Fournier's gangrene. Ther Adv Urol. 2015;7:203-15

29. Ozturk E, Sonmez Y, Yilmazlar T. What are the indications for a stoma in Fournier's gangrene?. Colorectal Dis. 2011;13:1044-7.

30. Mallikarjuna MN, Vijayakumar A, Patil VS, Shivswamy BS. Fournier's gangrene: current practices. ISRN Surg. 2012;2012:942437.

31. Yanar H, Taviloglu K, Ertekin C, Guloglu R, Zorba U, Cabioglu N, et al. Fournier's gangrene: risk factors and strategies for management. World J Surg. 2006;30:1750-4.

32. Hollabaugh RS, Dmochowski RR, Hickerson WL, Cox CE. Fournier's gangrene: therapeutic impact of hyperbaric oxygen. Plast Reconstr Surg. 1998;101:94-100.

33. Karian LS, Chung SY, Lee ES. Reconstruction of defects after Fournier gangrene: a systematic review. Eplasty. 2015;15:e18.

34. Chen SY, Fu JP, Chen TM, Chen SG. Reconstruction of scrotal and perineal defects in Fournier's gangrene. J Plast Reconstr Aesthet Surg. 2011;64:528-34

35. Carvalho JP, Hazan A, Cavalcanti AG, Favorito LA. Relation between the area affected by Fournier's gangrene and the type of reconstructive surgery used. A study with 80 patients. Int Braz J Urol. 2007;33:510-4. 